\title{
Adipocyte Hypertrophy and Improved Postprandial Lipid Response in Beta 2 Syntrophin Deficient Mice
}

\author{
Sabrina Krautbauer ${ }^{a} \quad$ Markus Neumeier ${ }^{\mathrm{a}} \quad$ Lisa Rein-Fischboeck $^{\mathrm{a}}$ \\ Elisabeth M. Haberla Herbert Tilg ${ }^{b} \quad$ Kristina Eisinger ${ }^{a} \quad$ Christa Buechler $^{a}$ \\ aDepartment of Internal Medicine I, Regensburg University Hospital, Regensburg, Germany,

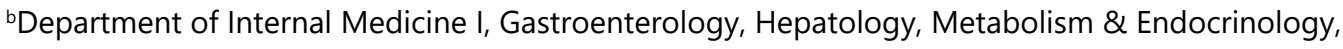 \\ Medical University Innsbruck, Innsbruck, Austria
}

\section{Key Words}

Collagen $\bullet$ Lipid droplet $\cdot$ Caveolin-1 $\bullet$ Free fatty acids $\bullet$ Liver

\begin{abstract}
Background/Aims: Adipocyte hypertrophy in obesity is associated with inflammation and adipose tissue fibrosis which both contribute to metabolic diseases. Mechanisms regulating lipid droplet expansion are poorly understood. Knock down of the scaffold protein beta 2 syntrophin (SNTB2) increases lipid droplet size of 3T3-L1 adipocytes and the physiological relevance of SNTB2 in adipose tissue morphology and metabolic health was analyzed herein. Methods: Wild type and SNTB2 $\%$ mice were challenged with 24 weeks high fat diet. Adipose tissue morphology and expression of various genes / proteins including collagens and caveolin-1 was examined. Glucose, insulin, fasting and fed free fatty acids were measured in serum. SNTB2 expression was determined in adipose tissues of patients. Results: Upon high fat diet SNTB2 $-1-$ mice displayed reduced adiposity and adipocyte hypertrophy. Expression of various proteins was normal in the different white fat depots of SNTB2 $2^{-1}$ mice while caveolin-1 protein and collagen mRNA levels were diminished. Null mice had reduced systemic glucose while fasting and postprandial insulin and insulin response were normal. Fatty acid clearance in the fed state and after insulin injection was enhanced. SNTB2 and caveolin-1 were increased in fat of ob/ob mice. However, no correlation between body mass index and SNTB2 protein in adipose tissues of seven patients was found. In subcutaneous but not in visceral fat the ratio of SNTB2 to alpha syntrophin protein, which affects lipid droplet size in the opposite manner, was associated with BMI. In subcutaneous fat of extremely obese patients SNTB2 mRNA levels were not correlated with weight loss after bariatric surgery. Conclusion: Current study shows that high SNTB2 in obese adipose tissues restricts adipocyte growth and thereby may contribute to metabolic diseases.

(C) 2019 The Author(s). Published by Cell Physiol Biochem Press GmbH\&Co. KG




\section{Cellular Physiology Cell Physiol Biochem 2019;52:1151-1165 \\ \begin{tabular}{ll|l} 
and Biochemistry & $\begin{array}{l}\text { DOl: 10.33594/000000078 } \\
\text { Published online: } 17 \text { April 2019 }\end{array}$ & $\begin{array}{l}\text { O } 2019 \text { The Author(s). Published by } \\
\text { Cell Physiol Biochem Press GmbH\&Co. KG }\end{array}$ \\
\cline { 2 - 3 }
\end{tabular} \\ Krautbauer et al.: SNTB2 Deficiency Improves Metabolic Health in Obesity}

\section{Introduction}

Adipose tissue is now well accepted as an endocrine organ. White fat secretes a variety of proteins which regulate glucose and lipid metabolism, blood pressure, immune system, and reproduction [1-5]. Adipose tissue grows when excess triglycerides have to be stored. Increased proliferation of precursor cells and subsequent differentiation to adipocytes augments lipid deposition. Adipocytes also store additional triglycerides by enlarging lipid droplet size and cell volume [6-8]. Ongoing adipocyte hypertrophy is a stressful condition causing hypoxia, inflammation, and fibrosis in fat tissues [9].

The adaptor proteins of the syntrophin family have been mostly studied in skeletal muscle where they are part of the dystrophin associated protein complex [10]. Alpha syntrophin (SNTA) and beta 2 syntrophin (SNTB2) are also expressed in adipocytes [11-13]. Recent work from our group showed that small lipid droplets are formed upon the knock down of SNTA during 3T3-L1 adipogenesis [11]. SNTA null mice have small adipocytes, are less obese, and are protected from lipid accumulation in skeletal muscle and the liver in a high fat diet model [14]. Knock down of SNTB2 during 3T3-L1 cell adipogenesis enables the formation of large lipid droplets [12]. Effects of SNTA and SNTB2 on lipid droplet size in 3T3L1 cells are independent of adipogenesis and expression of proteins mostly upregulated in differentiated adipocytes is not changed $[11,12]$. Thus, 3T3-L1 adipocytes with low SNTB2 have normal insulin-induced Akt phosphorylation [12]. Basal and $\beta$-adrenergic lipolysis are similar to controls while insulin stimulated antilipolytic effect is enhanced [12]. This pathway includes activation of phosphodiesterase 3B, which hydrolyzes cAMP and cGMP [15]. How SNTB2 controls the lipolysis inhibitory effect of insulin is unknown.

Impaired antilipolytic activity contributes to dyslipidemia and hyperglycemia which are involved in the pathogenesis of insulin resistance, non-alcoholic fatty liver disease and cardiovascular diseases [15-17].

Syntrophins are well described dystrophin binding proteins and regulate localization of neuronal nitric oxide synthase and aquaporin 4 in skeletal muscle $[18,19]$. Utrophin is a dystrophin homologous protein and binds to SNTB2 [10]. Loss of utrophin is associated with strongly reduced SNTB2 protein in the kidney and 3T3-L1 adipocytes $[12,20]$. Low utrophin does not grossly affect adipogenesis of 3T3-L1 cells. The formation of larger lipid droplets is most likely due to the fact that SNTB2 is downregulated [12].

Colocalization of utrophin with caveolin-1 has been described in lipid rafts of human umbilical vein endothelial cells while SNTB2 has not been analyzed in this study [21]. Caveolin-1 knock-out mice develop lipodystrophy at an older age but the underlying mechanisms have not been fully resolved [22]. Caveolin-1 deficiency in adipocytes does neither impair differentiation nor lipid droplet growth and further studies have to unravel why these mice are lipodystrophic [22-25].

Islet cell autoantigen binds to the SNTB2 - utrophin complex in pancreatic $\beta$-cells and is thereby protected from proteolysis. Release of islet cell autoantigen from SNTB2 is involved in insulin exocytosis [26] but whether insulin is changed in serum of SNTB2 deficient mice has not been evaluated to our knowledge so far. In animals deficient of SNTB2 and SNTA serum insulin is normal [27].

The activity of the $\alpha$ (1D)-adrenergic receptor is enhanced by binding to SNTB2 [28]. This receptor is expressed in adipose tissue [29] and $\alpha_{1}$-adrenoreceptor agonists may increase basal lipolysis [30]. Altered basal lipolysis has not been observed in adipocytes with low SNTB2 [12] excluding that this complex is of importance in these cells.

Aim of the present study was the analysis of adipose tissue morphology and gene / protein expression of SNTB2 deficient mice. Systemic glucose and lipid level, and insulin response were examined as measures of metabolic health. 


\section{Cellular Physiology Cell Physiol Biochem 2019;52:1151-1165 \\ \begin{tabular}{ll|l} 
and Biochemistry & $\begin{array}{l}\text { DOl.33594/000000078 } \\
\text { Published online: } 17 \text { April 2019 }\end{array}$ & $\begin{array}{l}\text { O } 2019 \text { The Author(s). Published by } \\
\text { Cell Physiol Biochem Press GmbH\&Co. KG }\end{array}$
\end{tabular} \\ Krautbauer et al.: SNTB2 Deficiency Improves Metabolic Health in Obesity}

\section{Materials and Methods}

\section{Human adipose tissue}

Paired samples of subcutaneous and visceral adipose tissues of seven patients (four males) undergoing surgery were obtained. Median age was $62(22-76)$ years and the median body mass index was $25.6(24.0$ - 29.7) $\mathrm{kg} / \mathrm{m}^{2}$. The study protocol was approved by the local ethics committee of the Regensburg University Hospital and was carried out in accordance with the Helsinki guidelines. All patients gave written informed consent. SNTB2 mRNA was further analyzed in human subcutaneous adipose tissues of 14 morbid obese patients (four males) which were collected before laparoscopic adjustable gastric banding surgery. RNA expression of nine patients was also determined six months after surgery. Median BMI was 43.6 (37.2 $50.5) \mathrm{kg} / \mathrm{m}^{2}$ before surgery and $36.9(26.4-42.44) \mathrm{kg} / \mathrm{m}^{2}$ six months after the intervention $(\mathrm{p}<0.001)$. Median age was 37 (21.4 - 52.3) years. The study protocol was approved by the ethics committee of the Medical University Innsbruck and patients provided written informed consent [31].

\section{Animals}

SNTB2 deficient mice have been described elsewhere [32] and 21 male animals were used. Twentythree wild type mice served as controls. Mice were maintained on a $12 \mathrm{~h}$ dark / light cycle and housed in groups of four to five animals per cage. Animals (12 weeks old) had unlimited access to water and high fat diet for 24 weeks (Ssniff EF R/M, D12451). Tissues were obtained from overnight fasted mice. Serum was also obtained from overnight fasted mice $2 \mathrm{~h}$ after giving food ( 8 wild type and 7 mutant mice).

Some of the animals were intraperitoneally injected with insulin (Humulin S, Lilly S.A., Madrid, Spain) which is dissolved in water according to the product insert ( 3 animals per group, $1 \mathrm{mU} / \mathrm{g}$ body weight) or water ( 4 animals per group) as control and tissues were obtained 10 min later.

An area of about $40,000 \mu^{2}$ per animal of formalin-fixed paraffin-embedded tissues was analyzed to determine adipocyte volume. Analysis was done with the AxioVision Rel. 4.8 software (Carl Zeiss Microscopy $\mathrm{GmbH}$, Oberkochen, Germany).

The $5 \mathrm{ob} / \mathrm{ob}$ mice and the corresponding 5 wild type animals were from Charles River Laboratories (Sulzfeld, Germany). Tissues were isolated from 13 weeks old male mice. Procedures were approved by the University of Regensburg Laboratory Animal Committee and complied with the German Law on Animal Protection and the Institute for Laboratory Animal Research Guide for the Care and Use of Laboratory Animals, 1999. Experiments were conducted according to institutional and governmental regulations for animal use (Government of the Oberpfalz).

\section{Assays and ELISAs}

QuantiChrom ${ }^{\mathrm{TM}}$ Glucose Assay Kit was from Biotrend (Köln, Germany). IP/Co-IP Kit Pierce Protein A/G Magnetic was from Thermo Scientific (Schwerte, Germany). Triglyceride concentrations were measured using GPO-PAP micro-test (Roche). Free fatty acids, glycerol and cholesterol were determined by assays from BioCat. The cAMP ELISA was from EnzoLife Science (Lörrach, Germany). Insulin ELISA was from Mercodia (Uppsala, Sweden).

Cell culture and siRNA transfection

3T3-L1 preadipocytes were from the American Type Culture Collection (ATCC, Manassas, VA, USA) and differentiated as described [33]. Transfection of preadipocytes with siRNAs was performed with XtremeGene transfection reagent (Roche, Mannheim, Germany) or Endoporter (Gene Tools LLC, Philomath, Oregon, USA) [12].
Table 1. Oligonucleotides used for real-time RT-PCR analysis

\begin{tabular}{lcc}
\hline Oligonucleotide & Sequence $\left(5^{\prime} \rightarrow 3^{\prime}\right)$ & PCR product $(\mathrm{bp})$ \\
\hline 18S rRNA_uni & GAT TGA TAG CTC TTT CTC GAT TCC & 217 \\
18S rRNA_rev & CAT CTA AGG GCA TCA CAG ACC & \\
Chemerin_uni & AAA CAC CCA CCT GTG CAG T & 213 \\
Chemerin_rev & TTT TAC CCT TGG GGT CCA TT & \\
CIDEA_uni & AAA CCA TGA CCG AAG TAG CC & 172 \\
CIDEA_rev & CGT GTT GTC CCT TAA GGT CTG & 182 \\
F4/80_uni & TGC TCT TCC TGA TGG TGA GA & 182 \\
F4/80_rev & CCC CGT CTC TGT ATT CAA CC & \\
G6PDH_uni & CGT GCT CCA GCA TAA GCT CT & 356 \\
G6PDH_rev & GCT CAC CGT GTC CAA TGT AG & \\
IL-6_uni & TTC CAT CCA GTT GCC TTC TT & 231 \\
IL-6_rev & TTC TGC AAG TGC ATC ATC GT & \\
PEPCK_uni & CTT TGG TGG CCG TAG ACC T & 239 \\
PEPCK_rev & CGA ACA TCC ACT CCA GCA C & \\
\hline
\end{tabular}




\section{Cellular Physiology Cell Physiol Biochem 2019;52:1151-1165 \\ \begin{tabular}{ll|l} 
and Biochemistry $10.33594 / 000000078$ & Published online: 17 April 2019 & $\begin{array}{l}\text { ( } 2019 \text { The Author(s). Published by } \\
\text { Cell Physiol Biochem Press GmbH\&Co. KG }\end{array}$
\end{tabular} \\ Krautbauer et al.: SNTB2 Deficiency Improves Metabolic Health in Obesity}

Differentiated adipocytes were transfected by electroporation as described [12]. Sequences of the siRNAs used have been published earlier [12].

\section{Immunoblot and real-time RT- PCR}

Immunoblot and real-time RT-PCR analysis were performed as described [34, 35]. 18S rRNA was used for normalization of gene expression with the exception of data related to patients were GAPDH was used [31]. Primers and antibodies used are listed in table 1 and 2. RT $^{2}$ Profiler ${ }^{\mathrm{TM}}$ Arrays Mouse Extracellular Matrix Adhesion Molecules PCR Array (PAMM-013Z) experiments were performed by Qiagen (Hilden, Germany). Data were normalized to the mean values of $\beta$-actin, GAPDH and $\beta 2$-microglobulin.
Table 2. Antibodies used for immunoblot analysis (monoclonal antibody, mAB; polyclonal antibody, pAB)

\begin{tabular}{lcc}
\hline Antigen & Catalog number & Company \\
\hline Anti-ABCA1 & ab18180 & Abcam \\
Anti-Adipophilin pAB & ab37516 & Abcam \\
Anti-Akt mAB & 4691 & Cell Signaling Technologies \\
Anti-AMPK pAB & 2532 & Cell Signaling Technologies \\
Anti-ATGL (30A4) mAB & 2439 & Cell Signaling Technologies \\
Anti-Caveolin-1 (D46G3) mAB & 3267 & Cell Signaling Technologies \\
Anti-FABP4 pAB & 2120 & Cell Signaling Technologies \\
Anti-FAS (C20G5) mAB & 3180 & Cell Signaling Technologies \\
Anti-FSP27 pAB & NB100-430 & Novus \\
Anti-GAPDH (14C10) mAB & 2118 & Cell Signaling Technologies \\
Anti-GLUT4 (1F8) mAB & 2213 & Cell Signaling Technologies \\
Anti-GSK3beta pAB & 9315 & Cell Signaling Technologies \\
Anti-HSL pAB & 4107 & Cell Signaling Technologies \\
Anti-p38 MAPK pAB & 9212 & Cell Signaling Technologies \\
Anti-panSNT mAB & - & Prof. Marvin Adams \\
Anti-Perilipin (D418) pAB & 3470 & Cell Signaling Technologies \\
Anti-PGC1 $\alpha$ & ab106814 & Abcam \\
Anti-Phospho-Akt (D9E) mAB & 4060 & Cell Signaling Technologies \\
Anti-Phospho-AMPK pAB & 2531 & Cell Signaling Technologies \\
Anti-phospho-GSK3beta pAB & 9336 & Cell Signaling Technologies \\
Anti-Phospho-p38 MAPK pAB & 4511 & Cell Signaling Technologies \\
Anti-Prdm 16, pAB & PA5-20872 & Thermo Fisher Scientific \\
Anti-SNTB2 pAB & - & Prof. Marvin Adams \\
Anti-UCP1, pAK & 10983 & Abcam \\
\hline
\end{tabular}

\section{Statistical Analysis}

Data are shown as box plots indicating median, lower and upper quartiles and range of the values. Outliners (greater than 1.5 times the interquartile range) and outliners (greater than 3.0 times the interquartile range) are given as circles or stars, respectively. Data in Fig. $1 \mathrm{~A}$ are given as mean \pm SEM. Statistical differences were analyzed by two-tailed Mann-Whitney U Test (SPSS Statistics 21.0 program) or t-test (Ms Excel) and a value of $\mathrm{p}<0.05$ was regarded as significant.

\section{Results}

\section{Reduced fat mass in SNTB2\% mice}

Recent experiments identified larger lipid droplets (LDs) in 3T3-L1 cells with low SNTB2 [12]. To evaluate a possible role of SNTB2 in adipose tissue morphology, SNTB2 deficient animals and the respective wild type mice were fed a high fat diet for 24 weeks. Body weight of the two groups was comparable at the beginning of the intervention and similarly increased in both genotypes (Fig. 1A). Food uptake was about 3 g per day and was comparable in both strains (data not shown). Subcutaneous and intraabdominal fat pad weights were nevertheless reduced in the knock-out mice (Fig. 1B).

Expression of F4/80 and IL-6 which are markers for macrophage number and inflammation was similar in subcutaneous, epididymal and perirenal fat depots of the mice (Fig. 1C and Table 3).

\section{Hypertrophic adipocytes in SNTB2\% mice}

Adipocyte size closely resembles lipid droplet dimension. Low SNTB2 promoted the formation of large LDs in 3T3-L1 cells [12]. Quantitative assessment of cell size in high fat diet fed animals showed a clear shift to larger adipocytes in perirenal and subcutaneous adipose tissues of SNTB2\% mice and a trend in epididymal fat (Fig. 1D - F). Adipocyte size is positively correlated with fat pad weight [36]. Therefore, cell volume was divided by the weight of the respective fat pads and is given as adipocyte volume per $g$ weight of the respective adipose tissue (Fig. 1D - F). 


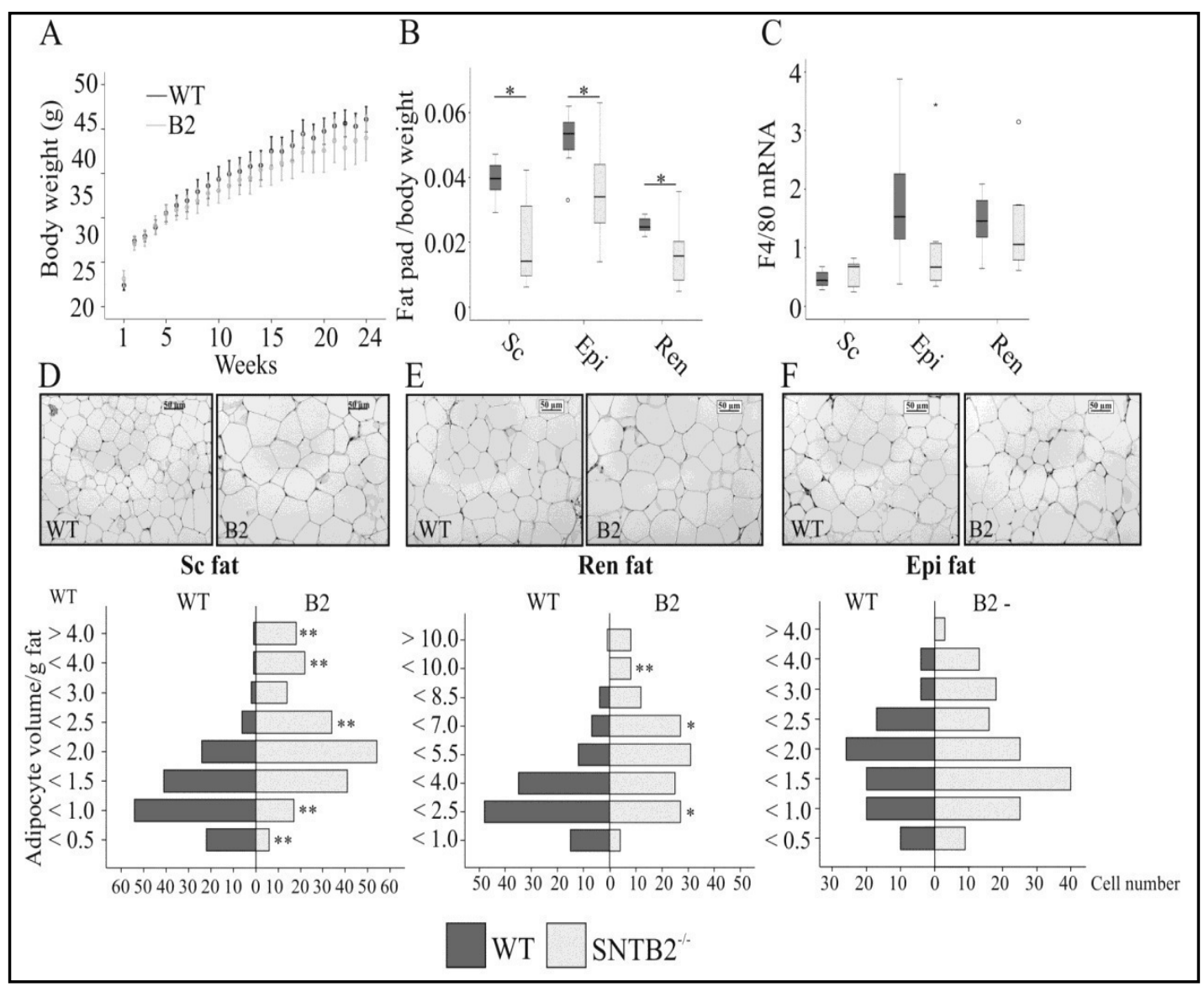

Fig. 1. Adipocyte hypertrophy and reduced fat pad weights in SNTB2\% mice. A. Body weight of 8 wild

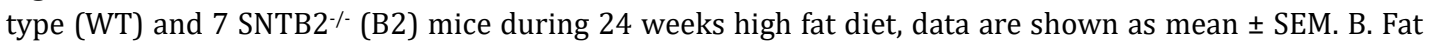
pad weight / body weight of wild type and SNTB2 $\%$ mice after 24 weeks high fat diet. C. F4/80 mRNA in the different fat pads of wild type and SNTB2 $\%$ mice. D. H\&E-stained tissue sections of subcutaneous adipose tissues. Subcutaneous adipocyte volumes are given below. The volumes were normalized to the weight of this adipose tissue (g) of WT and SNTB2 $\%$ mice. E. H\&E-stained tissue sections of perirenal adipose tissue. Perirenal adipocyte volumes are given below. The volumes were normalized to the weight of perirenal adipose tissue (g) of WT and SNTB2 $\%$. F. H\&E-stained tissue sections of epididymal adipose tissue. Epididymal adipocyte volumes are given below. The volumes were normalized to the weight of epididymal adipose tissue (g) of WT and SNTB2 $\%$ mice. Subcutaneous, sc; epididymal, epi; perirenal, ren, ${ }^{*} \mathrm{p}<0.05,{ }^{* *}$ $\mathrm{p}<0.01$.

Reduced caveolin-1 in fat tissues of SNTB2\% mice

Protein levels of enzymes involved in lipolysis (adipose triglyceride lipase (ATGL), hormone-sensitive lipase (HSL), perilipin), fatty acid metabolism (Acetyl-CoA carboxylase (ACC), fatty acid synthase (FAS), stearoyl-CoA desaturase-1 (SCD1) and fatty acid binding protein 4 (FABP4)) or lipid droplet associated proteins (adipophilin, fat-specific protein 27 (FSP27)) were not changed in the different white fat depots of SNTB2\% mice (Fig. 2A, B and data not shown). ATP-binding cassette transporter A1 (ABCA1) has been identified as a syntrophin binding protein [37] but total ABCA1 protein was normal in the fat depots of the mutant mice (Fig. 2B and data not shown).
Table 3. Expression of IL-6 mRNA in subcutaneous (sc), epididymal (epi) and perirenal (ren) adipose tissue of wild type (WT) and mutant mice

\begin{tabular}{lcc}
\hline & WT & SNTB2 $\%$ \\
\hline Number of animals & 8 & 7 \\
IL-6 sc & $0.053(0.02-0.17)$ & $0.135(0.04-0.26)$ \\
IL-6 epi & $0.303(0.04-1.51)$ & $0.919(0.18-7.97)$ \\
IL-6 ren & $0.125(0.05-0.48)$ & $0.125(0.05-0.14)$ \\
\hline
\end{tabular}




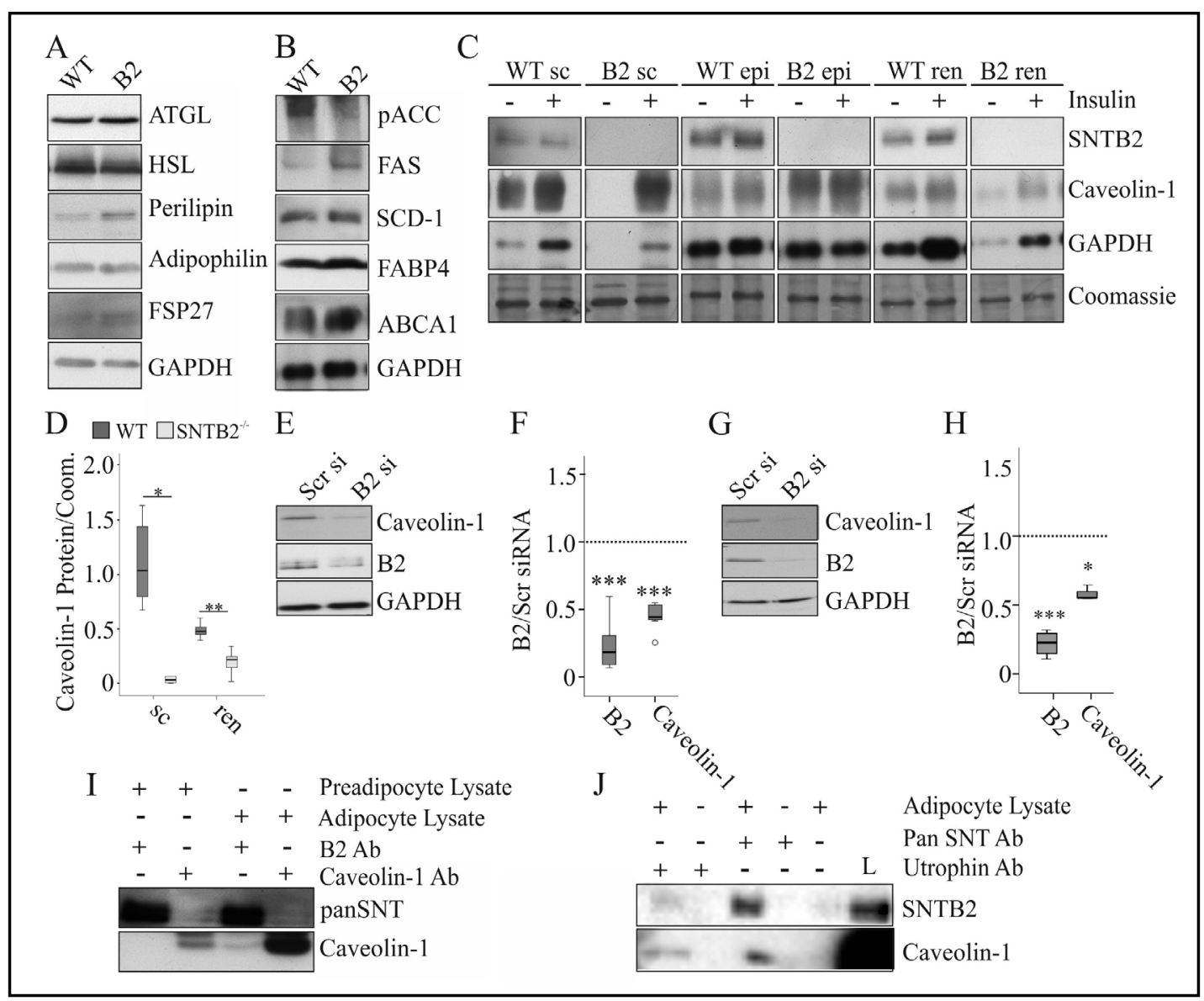

Fig. 2. Low caveolin-1 protein in fat tissues of SNTB2 $\%$ mice and upon knock down of SNTB2 in 3T3-L1 cells. A. ATGL, HSL, perilipin, adipophilin and FSP27 in epididymal (epi) fat of wild type (WT) and SNTB2\% (B2) animals. B. pACC, FAS, SCD-1, FABP4 and ABCA1 protein in epi fat of these animals. C. SNTB2 and caveolin-1 in subcutaneous (sc), epi and perirenal (ren) fat of WT and SNTB2 $\%$ animals injected with insulin or water. D. Quantification of caveolin-1 protein in sc and ren fat of 8 WT and 7 SNTB2\% animals. E. Caveolin-1, SNTB2 and GAPDH in mature 3T3-L1 adipocytes differentiated from preadipocytes which were transfected with scrambled or SNTB2 siRNA before differentiation. F. Protein densitometry of SNTB2 and caveolin-1 in the cells described in E ( $n=4-20)$. G. Caveolin-1, SNTB2 and GAPDH in 3T3-L1 adipocytes transfected with scrambled or SNTB2 siRNA after differentiation. H. Protein densitometry of SNTB2 and caveolin-1 in the cells described in $\mathrm{G}(\mathrm{n}=7$ - 11). I. Analysis of syntrophins (using the pan syntrophin antibody) and caveolin-1 in proteins precipitated by SNTB2 or caveolin-1 antibodies from preadipocyte and adipocyte lysates. J. Analysis of SNTB2 and caveolin-1 protein precipitated from adipocyte lysate using antibodies specific for syntrophins or utrophin. Lysate, $\mathrm{L} ;{ }^{*} \mathrm{p}<0.05,{ }^{* *} \mathrm{p}<0.01,{ }^{* * *} \mathrm{p}<0.001$.

Caveolin-1 protein was significantly diminished in subcutaneous and perirenal fat (Fig. 2C, D).

To investigate a possible relationship between SNTB2 and caveolin-1 in adipocytes, SNTB2 was knocked down in preadipocytes and cells were subsequently differentiated to mature adipocytes. These cells had reduced SNTB2 and caveolin-1 protein (Fig. 2E, F). Knock down of SNTB2 in mature adipocytes also diminished SNTB2 and caveolin-1 protein (Fig. $2 \mathrm{G}, \mathrm{H})$. These results demonstrate that SNTB2 regulates caveolin-1 levels independent from adipogenesis. Co-immunoprecipitation experiments showed that little caveolin-1 protein is associated with SNTB2 (Fig. 2I, J). Using the utrophin antibody even less caveolin-1 was immunoprecipitated suggesting that there is little if any utrophin / SNTB2 / caveolin-1 complex in adipocytes. 


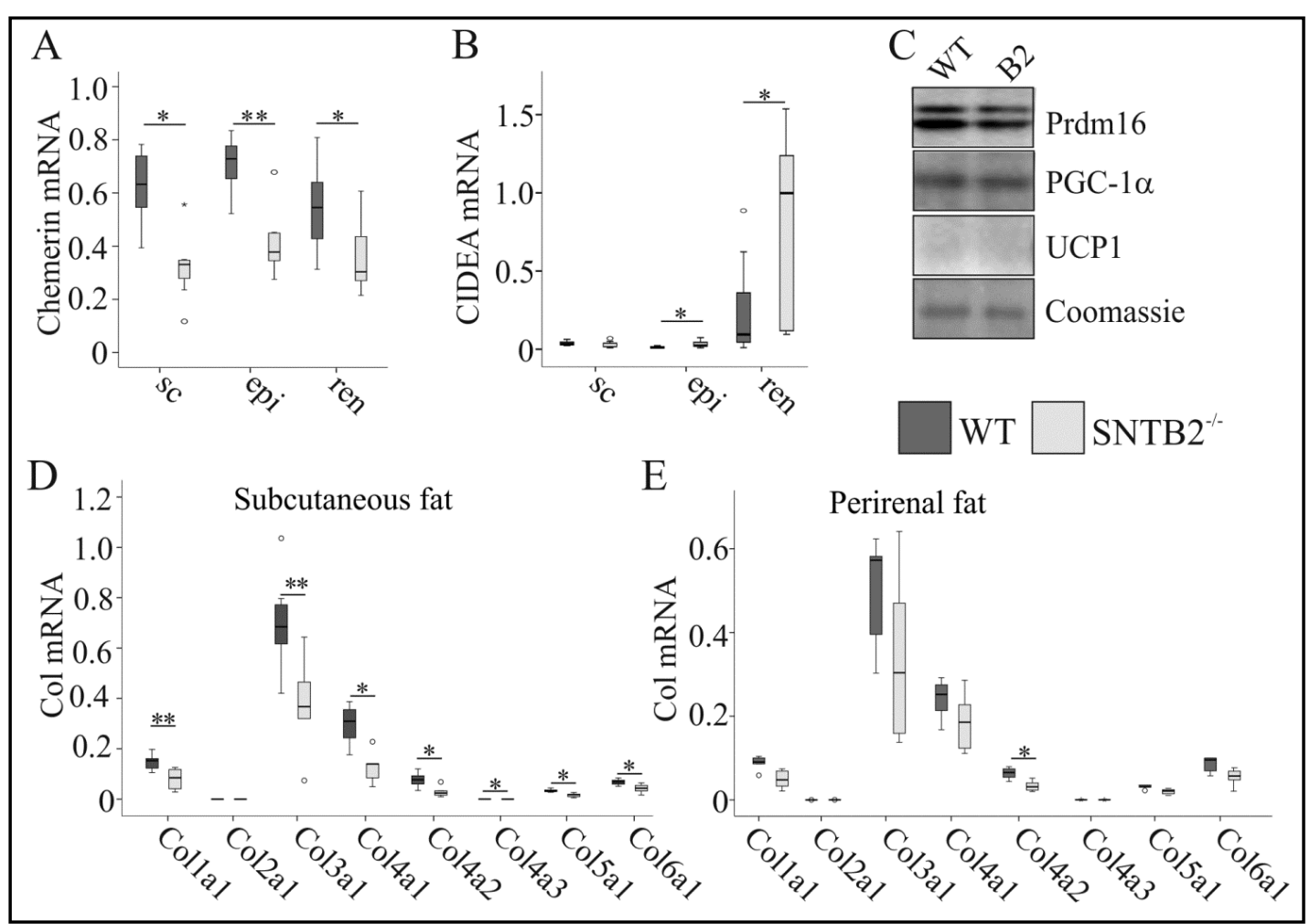

Fig. 3. Chemerin, CIDEA and collagen mRNAs are changed in fat tissues of SNTB2 $\%$ mice. A. Chemerin mRNA levels in the different fat pads. B. CIDEA mRNA expression in the different fat pads. C. Prdm16, PGC-1 $\alpha$ and UCP1 protein in epididymal fat of wild type (WT) and SNTB2\% (B2) mice. Coomassie stained membrane is shown as loading control. D. Collagen isoform mRNA levels in subcutaneous fat of 8 wild type and 6 SNTB21- mice. E. Collagen isoform mRNA levels in perirenal fat of 6 wild type and 6 SNTB2 $\%$ mice. Subcutaneous, sc; epididymal, epi; perirenal, ren, ${ }^{*} \mathrm{p}<0.05$; ${ }^{* *} \mathrm{p}<0.01$.

Reduced chemerin and collagen mRNA in fat tissues of SNTB2\% mice

Chemerin is induced in hypertrophic adipocytes [33]. Analysis of chemerin mRNA expression revealed lower levels in all fat depots of the mutant animals (Fig. 3A). CIDEA mRNA, which is highly expressed in brown fat [38], was increased in the intraabdominal adipose tissues of the null mice (Fig. 3B). UCP1 was hardly detectable in white fat while Prdm16 and PGC1 $\alpha$, typically expressed in brown fat [38], were not changed in the null mice (Fig. 3C).

Remodeling of the extracellular matrix accompanies adipose tissue expansion and adipocyte growth $[39,40]$. Collagens $1,2,3,4,5$ and 6 were expressed in adipose tissue and all but collagen $2 \mathrm{a} 1$ were reduced in subcutaneous fat of SNTB2 $\%$ mice (Fig. 3D). In perirenal fat, collagen $4 \mathrm{a} 2$ was lower and collagen $1 \mathrm{a} 1$ and $5 \mathrm{a} 1$ tended to be diminished (Fig. 3E).

\section{Metabolic improvement in SNTB2\% mice}

Deletion of collagen 6 allows unrestricted adipocyte growth which is associated with metabolic improvements in obesity [39]. Expression of several collagen isoforms was diminished in fat of SNTB2 $\%$ mice (Fig. 3D, E) and this may be linked to metabolic health. Fasting serum glucose was indeed reduced in SNTB2 $\%$ mice on a high fat diet (Fig. 4A). Insulin stimulated phosphorylation of Akt in the different fat depots, the liver and skeletal muscle was nevertheless comparable in both genotypes and intraperitoneal insulin tolerance test was normal (Fig. 4B - F and data not shown). Fasting and fed insulin levels of SNTB2 $\%$ mice and wild type mice were similar (Fig. 5A and data not shown). 


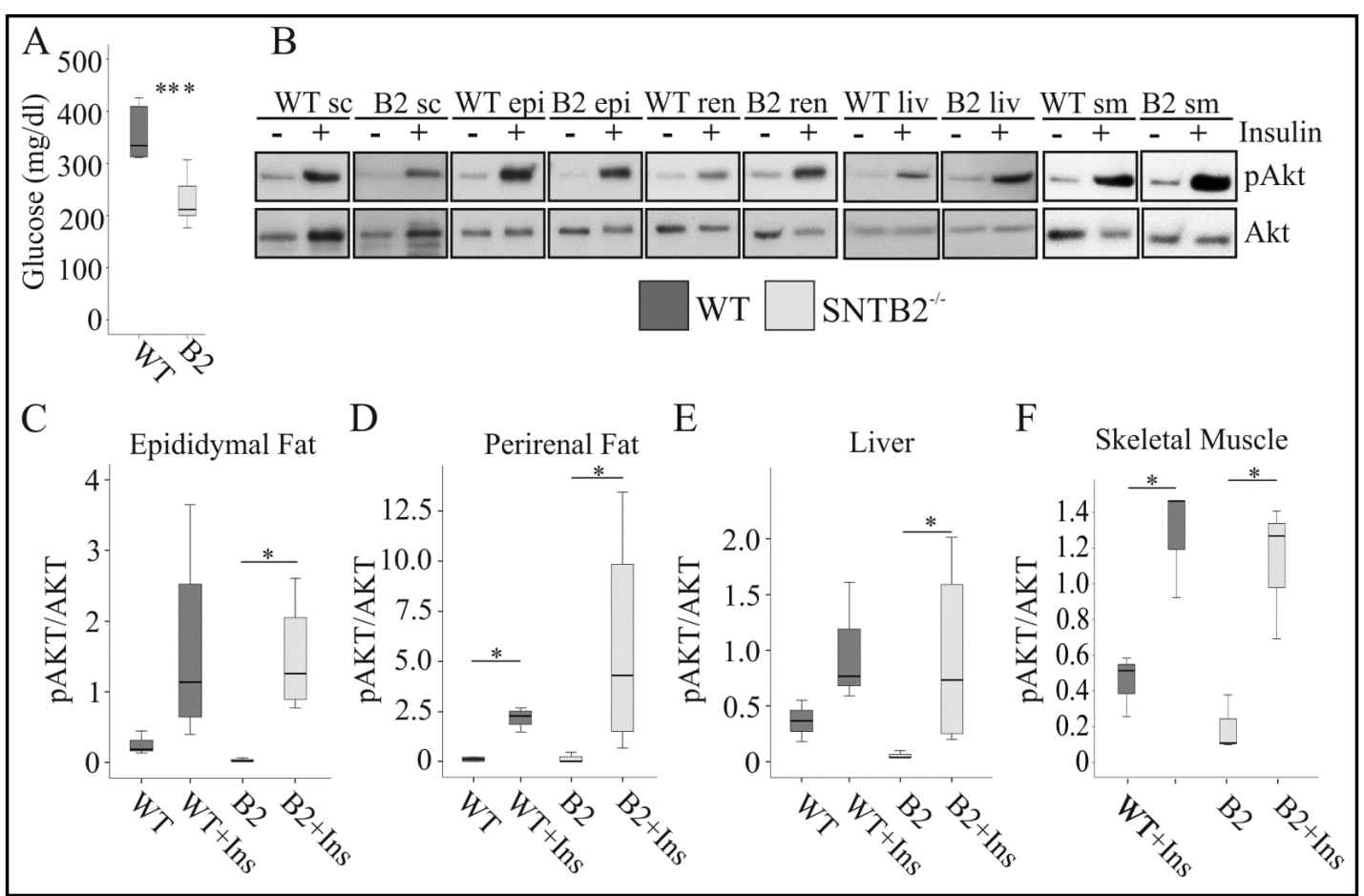

Fig. 4. Reduced fasting glucose and normal insulin response of SNTB $\%$ animals. A. Fasting serum glucose of wild type and SNTB2 ${ }^{--}$mice. B. pAkt and Akt 10 min after intraperitoneal $\mathrm{H}_{2} \mathrm{O}(-)$ or insulin (+) injection. Black borders correspond to where the image has been cropped. Quantification of pAkt / Akt in C. epididymal fat, D. perirenal fat, E, the liver and F, skeletal muscle $(n=3-4)$. Subcutaneous, sc; epididymal, epi; perirenal, ren; liver, liv; skeletal muscle, sm. ${ }^{*} \mathrm{p}<0.05,{ }^{* * *} \mathrm{p}<0.001$.

Further, there was no difference in free fatty acid and glycerol serum levels of fasted mice (Fig. 5B, C). Free fatty acids tended to be reduced $10 \mathrm{~min}$ after insulin injection in the wild type mice and were significantly diminished in the SNTB2\% animals (Fig. 5B). Serum glycerol was suppressed by insulin only in the knock-out mice (Fig. 5C). Similarly, free fatty acids and glycerol were lower in serum of SNTB2 $\%$ mice in the fed state (Fig. 5D, E). Insulin exerts its antilipolytic effects by decreasing cAMP [15]. This second messenger was not reduced when measured $10 \mathrm{~min}$ after insulin injection in the fat tissues of wild type and SNTB2 $\%$ mice (Fig. 5F). Levels of cAMP were nevertheless reduced in all white fat depots of the SNTB2 $\%$ mice (Fig. $5 \mathrm{~F}$ and data not shown).

\section{Reduced hepatic triglycerides}

Hepatic triglycerides were lower in the SNTB2 null mice (Fig. 5G). IL-6, F4/80, Col1a1 and alpha smooth muscle actin mRNAs were not changed in the liver (Table 4). The gluconeogenesis genes phosphoenolpyruvate carboxykinase and glucose-6-phosphatdehydrogenase were not regulated (Fig. 5H, I). GLUT4 involved in glucose uptake was induced in the liver (Fig. 5J). Phosphorylated AMP-activated protein kinase (AMPK) was not different in the liver of both genotypes (data not shown).

Phosphorylation of AMPK, glycogen synthase kinase 3 beta (GSK3beta) and p38 MAPK play central roles in cellular energy metabolism and protein synthesis [41, 42], but proteins were not altered in skeletal muscle of the null mice (Fig. 5K).

\section{SNTB2 is induced in adipose tissues of ob/ob mice}

The assumption that SNTB2 limits expansion of adipocytes suggests that SNTB2 is induced in hypertrophic adipose tissues of animals suffering from metabolic diseases. In subcutaneous, perirenal, and epididymal fat of the extremely obese ob/ob mice, SNTB2 


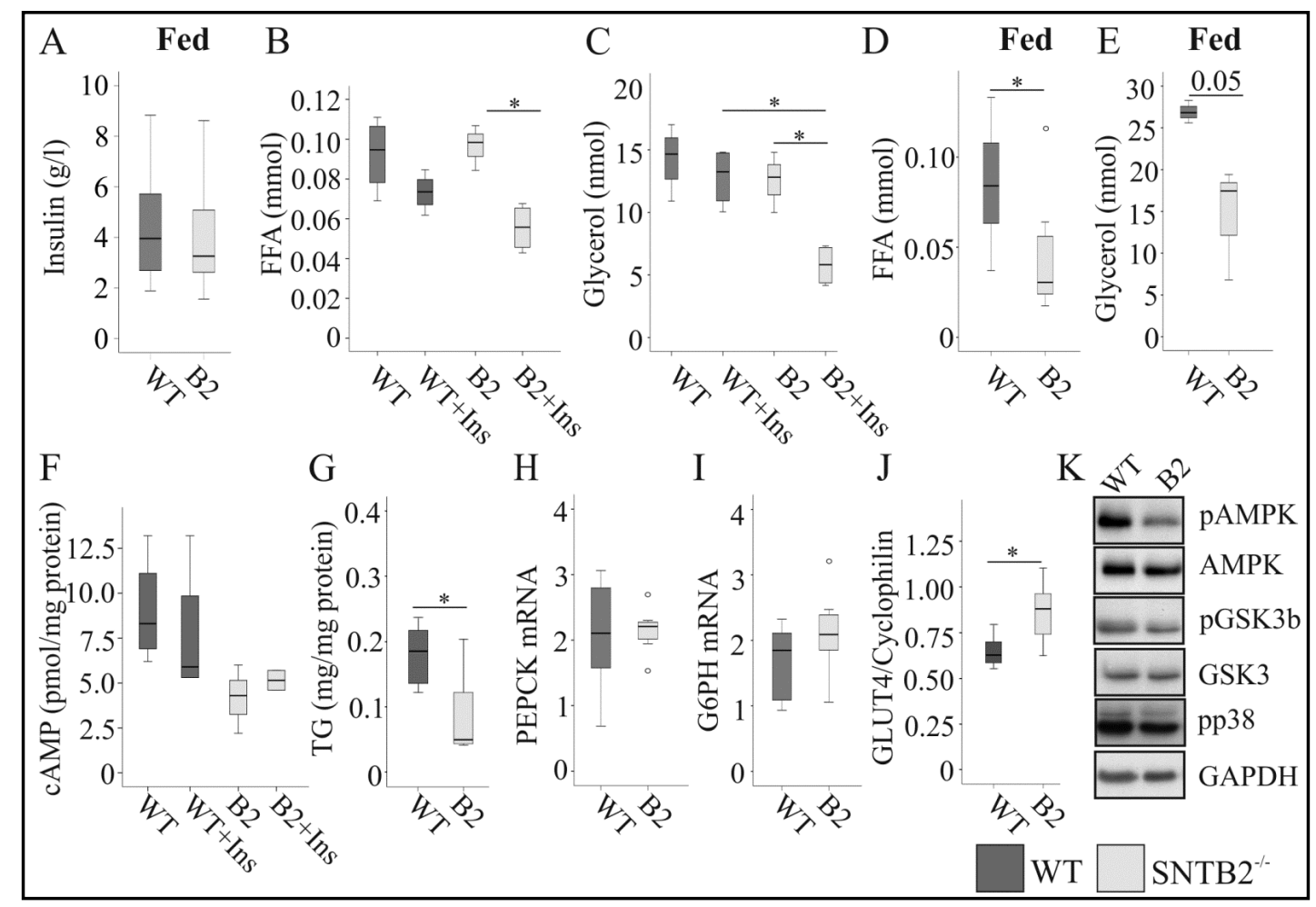

Fig. 5. Enhanced postprandial clearance of fatty acids, hepatic and skeletal muscle protein expression. A. Insulin serum levels in fed mice. B. Free fatty acid (FFA) serum levels in fasted mice after intraperitoneal $\mathrm{H}_{2} \mathrm{O}$ or insulin (Ins) injection ( $\mathrm{n}=3$ - 4). C. Serum glycerol in the animals described in B. D. Free fatty acid serum levels in fed mice $(n=7-8)$. E. Glycerol serum levels in fed mice $(n=7-8)$. F. cAMP in the subcutaneous fat pads after intraperitoneal $\mathrm{H}_{2} \mathrm{O}$ or insulin injection $(\mathrm{n}=3-4)$. The concentration measured by the respective assay is given in pmol per mg cellular protein content. G. Hepatic triglycerides in wild type and SNTB2\% mice ( $\mathrm{n}=7$ - 8). The concentration measured by the respective assay is given in mg per mg cellular protein content. H. Hepatic PEPCK mRNA in wild type and SNTB2 $\%$ mice ( $n=7-8)$. I. Hepatic G6PH mRNA in wild type and SNTB2 $\%$ mice ( $n=7$ - 8). J. Quantification of GLUT4 protein in the liver of wild type and SNTB2 $\%$ mice ( $n=7$ - 8). K. AMPK, GSK3beta, phosphorylated level of these proteins and phosphorylated p38 MAPK in skeletal muscle of wild type and SNTB2 $\%$ mice $(n=4)$. ${ }^{*}<<0.05$.

was higher compared to lean animals (Fig. 6A, B). Caveolin-1 was upregulated in subcutaneous and perirenal fat and tended to be elevated in epididymal fat of ob/ ob mice (Fig. 6A, C).

SNTB2 was comparably abundant in human subcutaneous and visceral fat which was available from seven donors. SNTB2 protein was not different in the fat depots of overweight compared to the normal weight donors (Fig. 6D, E).

Loss of SNTA is linked to small adipocytes while SNTB2 deficiency is associated with larger cell size [12,14]. Due to the fact that mice deficient in both syntrophin isoforms have normal adipocytes [27] the ratio of SNTB2 to SNTA may determine adipocyte size. The ratio of SNTB2 protein to SNTA protein in subcutaneous fat was indeed higher in the overweight patients (Fig. 6F). Such an effect was not seen in visceral adipose tissues of the identical donors (data not shown). SNTB2 / SNTA protein positively correlated with BMI (Fig. 6G).
Table 4. Expression of IL-6, F4/80, alpha smooth muscle actin (SMA) and collagen (Col) 1A1 mRNA in the liver of wild type (WT) and mutant mice

\begin{tabular}{lcc}
\hline & WT & SNTB2 $\%$ \\
\hline Number of animals & 8 & 7 \\
IL-6 & $0.037(0.02-0.35)$ & $0.037(0.02-0.10)$ \\
F4 $/ 80$ & $0.226(0.16-0.47)$ & $0.295(0.14-0.43)$ \\
Alpha SMA & $0.036(0.01-0.09)$ & $0.035(0.02-0.12)$ \\
Col1A1 & $0.060(0.03-0.13)$ & $0.053(0.03-0.13)$ \\
\hline
\end{tabular}




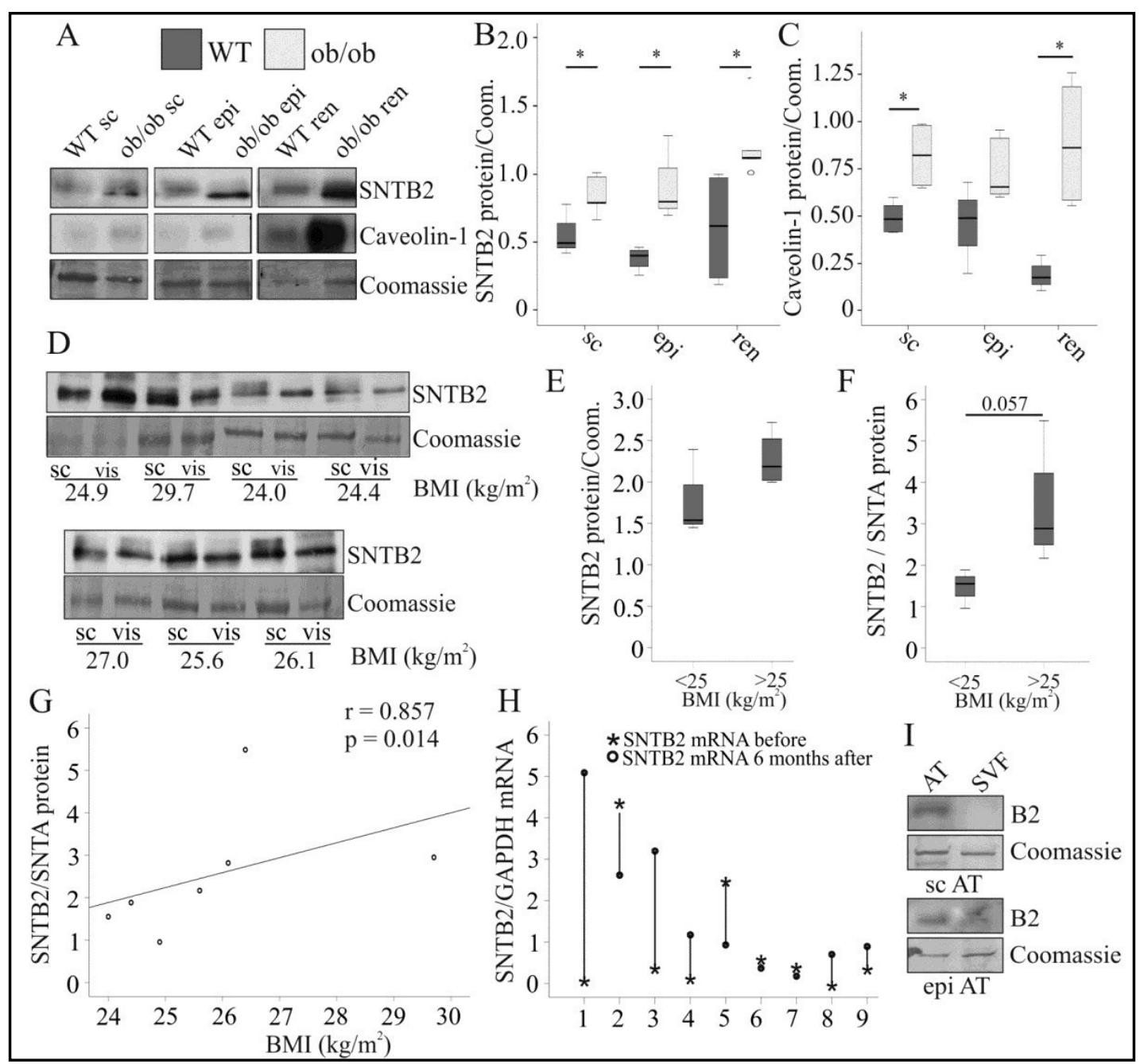

Fig. 6. SNTB2 is induced in fat of ob/ob mice and SNTB2 / SNTA ratio increases with BMI. A. SNTB2 and caveolin-1 in adipose tissues of wild type (WT) and ob/ob mice B. Protein densitometry of SNTB2 in the different fat depots ( $n=5$ per group). C. Protein densitometry of caveolin- 1 in the different fat depots $(n=$ 5 per group). D. SNTB2 in paired samples of sc and visceral fat of 7 patients. Coomassie stained membrane is shown as loading control. The respective BMIs are given below. E. SNTB2 protein in subcutaneous fat of 3 normal weight and 4 overweight patients. F. SNTB2 / SNTA protein ratio in subcutaneous fat of 3 normal weight and 4 overweight patients. G. Correlation of the SNTB2 / SNTA protein ratio with BMI. H. Subcutaneous adipose tissue SNTB2 mRNA in nine very obese patients before bariatric surgery and 6 months later. Subcutaneous, sc; epididymal, epi; perirenal, ren, ${ }^{*}$ p $<0.05$. I. SNTB2 in adipose tissue (AT) and stromal vascular cell fraction (SVF) of sc and epi fat.

In a separate experiment SNTB2 mRNA was determined in subcutaneous fat of morbidly obese patients before and 6 months after surgery. SNTB2 mRNA levels were unchanged in two patients, decreased in two patients and increased in five patients (Fig. 6H). SNTA mRNA expression was hardly detectable in these RNA samples and ratio could not be calculated.

Compared to total adipose tissue SNTB2 protein was very low expressed in the stromal vascular fraction isolated from subcutaneous and epididymal adipose (Fig. 6I). Therefore, expression of SNTB2 in total fat is mostly related to levels in adipocytes. 


\section{Cellular Physiology Cell Physiol Biochem 2019;52:1151-1165 \\ \begin{tabular}{ll|l} 
and Biochemistry & $\begin{array}{l}\text { DOl: 10.33594/000000078 } \\
\text { Published online: } 17 \text { April 2019 }\end{array}$ & $\begin{array}{l}\text { O } 2019 \text { The Author(s). Published by } \\
\text { Cell Physiol Biochem Press GmbH\&Co. KG }\end{array}$ \\
\cline { 2 - 3 }
\end{tabular} \\ Krautbauer et al.: SNTB2 Deficiency Improves Metabolic Health in Obesity}

\section{Discussion}

Adipocyte growth and subsequent adipose tissue fibrosis are closely linked to metabolic abnormalities in obesity [7, 43]. Adipocyte hypertrophy in SNTB2 knock-out mice is accompanied by a diminished expression of collagens suggesting a less rigid extracellular matrix which does not hinder cell expansion [39]. Animals do not display hyperglycemia and postprandial lipid clearance is improved showing that the null mice are protected from metabolic disease in obesity.

Enlarged adipocytes in SNTB2 null mice are not related to increased fat mass. On the contrary, the weight of white fat pads is even decreased. This is at least partially attributed to the reduced proliferation of preadipocytes [12], and metabolic health of the mutant mice may thus be related to less adiposity. SNTB2 is expressed in mesenchymal stem cells where it is localized in focal adhesions [44]. Commitment of these cells to osteogenic but not adipogenic differentiation is associated with the depletion of SNTB2 from these cellular structures [44]. Whether SNTB2 loss may thus impair the conversion of mesenchymal stem cells to preadipocytes needs further analysis.

Levels of various proteins induced during adipogenesis and having a central function in adipocyte lipid metabolism are not changed in fat tissues of SNTB2 $\%$ mice and in 3T3-L1 cells with low SNTB2 [12]. Thus, SNTB2 loss does not enhance adipogenic differentiation. In the 3T3-L1 cells larger lipid droplets are formed while the number of droplets per cell is reduced [12]. SNTB2 may influence the cellular localization of proteins involved in lipid droplet growth and analyzing lipid droplet proteome may give further insights in the molecular pathways regulated by this scaffold protein.

Caveolin-1 and SNTB2 are cholesterol-binding proteins [45, 46]. Caveolin-1 is markedly diminished when SNTB2 is low / absent. This assumes a direct role of SNTB2 in the regulation of cellular caveolin-1 protein levels. Little caveolin-1 co-immunoprecipitates with SNTB2 and utrophin, arguing against the stabilization of caveolin-1 protein by complex formation with SNTB2 and / or utrophin.

Caveolin-1 is not only reduced upon SNTB2 knock down in the cell line but is also low in fat tissues of SNTB2 $\%$ animals. This indicates a prominent function of SNTB2 in defining adipose tissue caveolin-1 levels. In ob/ob mice, caveolin-1 is clearly induced in white adipose tissues in line with some but contrasting with other findings [25, 47-50]. SNTB2 is also upregulated in obesity and thus may partly contribute to higher caveolin-1.

Besides caveolin-1, the expression of chemerin is reduced in fat tissues of SNTB2\% mice. Chemerin is upregulated in adipose tissues in obesity and this is mediated by inflammatory cytokines [33]. Here, IL-6 has been analyzed which is similarly expressed in the adipose tissues of both genotypes. Therefore, inflammatory pathways besides IL- 6 may be reduced in the fat tissues of SNTB2\% knock-out mice.

CIDEA is considered as a marker of brown fat [38], and is upregulated in intraabdominal adipose tissues of SNTB2 $\%$ animals. Other markers of beige fat [38] like Prdm16 are not changed excluding increased browning of white adipose tissues. CIDEA is involved in lipid droplet fusion [51] and thus might contribute to larger lipid droplets and adipocyte volume in SNTB2\% animals.

Collagen 6 deficiency in adipocytes enables adipocyte hypertrophy while peripheral insulin sensitivity improves [39]. Adipocyte enlargement in SNTB2 $\%$ animals does not alter insulin sensitivity. Postprandial fatty acid clearance is nevertheless enhanced in the SNTB2 $\%$ mice. Khan et al. demonstrate enhanced fatty acid removal during a lipid challenge when collagen 6 is deleted in fat [39]. This is not associated with any changes of circulating triglycerides in those mice [39]. Serum triglycerides are also normal in the SNTB2 $\%$ animals studied herein. Postprandial fatty acid spill-over contributes to hepatic triglycerides which are lower in both mouse models $[39,52]$. Cyclic AMP is reduced in the fat tissues of the mutant mice and this may enhance antilipolytic activity of insulin [53]. Therefore, SNTB2 seems to regulate antilipolytic pathways downstream of Akt which is normally activated in the mutant mice. Fasting and fed insulin are further not changed in the mutant mice. Insulin 


\section{Cellular Physiology Cell Physiol Biochem 2019;52:1151-1165

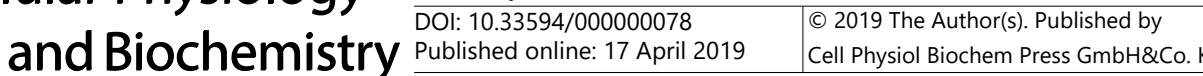

signaling may, therefore, neither be enhanced nor prolonged in the SNTB2 $\%$ mice. These data further exclude that SNTB2 affects insulin exocytosis in the mice [26].

Higher re-esterification rate of fatty acids in SNTB2\% mice lowers adipocyte glycerol release which augments hepatic glucose production and fasting serum glucose [15]. Hepatic glucose synthesis seems to be comparable to wild type mice, and PEPCK and G6PH are normally expressed, suggesting that higher glucose disposal in peripheral tissues explains lower fasting glucose of the null mice. Hepatic GLUT4 levels are induced in SNTB2\% animals in line with this assumption.

Reduced adiposity of SNTB2 $\%$ mice is not explained by lower nutrient uptake suggesting increased energy expenditure. Physical activity of SNTB2 $\%$ animals is comparable to wild type controls [32]. AMPK switches on catabolic pathways [41] but the phosphorylated form of AMPK is similarly abundant in liver and skeletal muscle of both genotypes. Future studies have to identify the pathways which contribute to less adiposity of the mutant mice.

Mice deficient in alpha-syntrophin (SNTA) and SNTB2 do not display any alterations in adipose tissue mass [27]. This suggests that SNTA and SNTB2 have diverge functions in accordance with recent findings regarding their role in the activation of adrenergic receptors [28]. The contrary effects of these isoforms on lipid droplet sizes suggests that deletion of both rescues to a wild type phenotype [12,14, 27].

In the few human adipose tissues analyzed, the ratio of SNTB2 to SNTA protein is induced in the subcutaneous fat of the overweight compared to normal weight donors. Whether inadequate levels of one isoform or both isoforms are associated with adipocyte volume and / or adiposity has to be confirmed in larger cohorts. SNTB2 mRNA is not changed in subcutaneous fat of morbidly obese patients after weight loss which is associated with a reduction in adipocyte volume [54]. SNTA mRNA was, however, hardly detectable in those samples and ratio could not be calculated.

One major problem in the obese is the inappropriate storage of lipids in fat tissues. Thus, enlargement of adipocytes in the SNTB2 $\%$ mice may indeed compensate for insufficient adipocyte number at least in the short-term. Later on in life continuously elevated supply with fat, which can't be stored by further growth of existing cells, and failure to provide more precursor cells may contribute to the known metabolic complications associated with obesity also in these animals.

\section{Conclusion}

In summary this study supports the idea that more healthy expansion of lipid droplets is protective against metabolic abnormalities associated with obesity. Upregulation of SNTB2 limits adipocyte expansion and contributes to adipose tissue stiffness and metabolic disease.

\section{Acknowledgements}

The study was supported by a grant from the German Research Foundation (BU 1141/8-1).

\section{Disclosure Statement}

The authors declare to have no competing interests. 


\section{Cellular Physiology Cell Physiol Biochem 2019;52:1151-1165 \begin{tabular}{l|l}
\hline DOI: 10.33594/000000078 & (c)19 The Author(s). Published by
\end{tabular} \\ \begin{tabular}{l|l} 
Published online: 17 April $2019 \quad$ Cell Physiol Biochem Press GmbH\&Co. KG \\
\hline
\end{tabular} \\ Krautbauer et al.: SNTB2 Deficiency Improves Metabolic Health in Obesity}

\section{References}

1 Asterholm IW, Scherer PE: Enhanced metabolic flexibility associated with elevated adiponectin levels. Am J Pathol 2010;176:1364-1376.

-2 Galic S, Oakhill JS, Steinberg GR: Adipose tissue as an endocrine organ. Mol Cell Endocrinol 2010;316:129139.

- 3 Lafontan M: Adipose tissue and adipocyte dysregulation. Diabetes Metab 2014;40:16-28.

- 4 Mattern A, Zellmann T, Beck-Sickinger AG: Processing, signaling, and physiological function of chemerin. IUBMB Life 2014;66:19-26.

- 5 Romacho T, Elsen M, Rohrborn D, Eckel J: Adipose tissue and its role in organ crosstalk. Acta Physiol (Oxf) 2014;210:733-753.

Berry R, Jeffery E, Rodeheffer MS: Weighing in on adipocyte precursors. Cell Metab 2014;19:8-20.

Buechler C, Krautbauer S, Eisinger K: Adipose tissue fibrosis. World J Diabetes 2015;6:548-553.

Guilherme A, Virbasius JV, Puri V, Czech MP: Adipocyte dysfunctions linking obesity to insulin resistance and type 2 diabetes. Nat Rev Mol Cell Biol 2008;9:367-377.

-9 Crewe C, An YA, Scherer PE: The ominous triad of adipose tissue dysfunction: inflammation, fibrosis, and impaired angiogenesis. J Clin Invest 2017;127:74-82.

-10 Bhat HF, Adams ME, Khanday FA: Syntrophin proteins as Santa Claus: role(s) in cell signal transduction. Cell Mol Life Sci 2013;70:2533-2554.

- 11 Eisinger K, Rein-Fischboeck L, Pohl R, Meier EM, Krautbauer S, Buechler C: The adaptor protein alphasyntrophin regulates adipocyte lipid droplet growth. Exp Cell Res 2016;345:100-107.

12 Krautbauer S, Neumeier M, Haberl EM, Pohl R, Feder S, Eisinger K, Rein-Fischboeck L, Buechler C: The utrophin-beta 2 syntrophin complex regulates adipocyte lipid droplet size independent of adipogenesis. Mol Cell Biochem 2018; DOI:10.1007/s11010-018-3409-6.

13 Romo-Yanez J, Montanez C, Salazar-Olivo LA: Dystrophins and DAPs are expressed in adipose tissue and are regulated by adipogenesis and extracellular matrix. Biochem Biophys Res Commun 2011;404:717-722.

- 14 Eisinger K, Rein-Fischboeck L, Neumeier M, Schmidhofer S, Pohl R, Haberl EM, Liebisch G, Kopp A, Schmid A, Krautbauer S, Buechler C: Alpha-syntrophin deficient mice are protected from adipocyte hypertrophy and ectopic triglyceride deposition in obesity. Exp Mol Pathol 2018;104:212-221.

15 Wang M, Fotsch C: Small-molecule compounds that modulate lipolysis in adipose tissue: targeting strategies and molecular classes. Chem Biol 2006;13:1019-1027.

16 Stumvoll M, Gerich J: Clinical features of insulin resistance and beta cell dysfunction and the relationship to type 2 diabetes. Clin Lab Med 2001;21:31-51.

17 Xia W, Pessentheiner AR, Hofer DC, Amor M, Schreiber R, Schoiswohl G, Eichmann TO, Walenta E, Itariu B, Prager G, Hackl H, Stulnig T, Kratky D, Rulicke T, Bogner-Strauss JG: Loss of ABHD15 Impairs the Antilipolytic Action of Insulin by Altering PDE3B Stability and Contributes to Insulin Resistance. Cell Rep 2018;23:1948-1961.

18 Adams ME, Mueller HA, Froehner SC: In vivo requirement of the alpha-syntrophin PDZ domain for the sarcolemmal localization of nNOS and aquaporin-4. J Cell Biol 2001;155:113-122.

-19 Adams ME, Odom GL, Kim MJ, Chamberlain JS, Froehner SC: Syntrophin binds directly to multiple spectrin-like repeats in dystrophin and mediates binding of nNOS to repeats 16-17. Hum Mol Genet 2018; DOI:10.1093/hmg/ddy197.

20 Haenggi T, Schaub MC, Fritschy JM: Molecular heterogeneity of the dystrophin-associated protein complex in the mouse kidney nephron: differential alterations in the absence of utrophin and dystrophin. Cell Tissue Res 2005;319:299-313.

21 Ramirez-Sanchez I, Mendoza-Lorenzo P, Zentella-Dehesa A, Mendez-Bolaina E, Lara-Padilla E, CeballosReyes G, Canto P, Palma-Flores C, Coral-Vazquez RM: Caveolae and non-caveolae lipid raft microdomains of human umbilical vein endothelial cells contain utrophin-associated protein complexes. Biochimie 2012;94:1884-1890.

22 Le Lay S, Blouin CM, Hajduch E, Dugail I: Filling up adipocytes with lipids. Lessons from caveolin-1 deficiency. Biochim Biophys Acta 2009;1791:514-518.

23 Gonzalez-Munoz E, Lopez-Iglesias C, Calvo M, Palacin M, Zorzano A, Camps M: Caveolin-1 loss of function accelerates glucose transporter 4 and insulin receptor degradation in 3T3-L1 adipocytes. Endocrinology 2009;150:3493-3502. 


\section{Cellular Physiology Cell Physiol Biochem 2019;52:1151-1165 \begin{tabular}{ll|l|}
\hline DOI: 10.33594/000000078 & O 2019 The Author(s). Published by \\
\hline
\end{tabular} and Biochemistry Published online: 17 April 2019 Cell Physiol Biochem Press GmbH\&Co. KG \\ Krautbauer et al.: SNTB2 Deficiency Improves Metabolic Health in Obesity}

-24 Meshulam T, Breen MR, Liu L, Parton RG, Pilch PF: Caveolins/caveolae protect adipocytes from fatty acidmediated lipotoxicity. J Lipid Res 2011;52:1526-1532.

-25 Mukherjee R, Kim SW, Choi MS, Yun JW: Sex-dependent expression of caveolin 1 in response to sex steroid hormones is closely associated with development of obesity in rats. PLoS One 2014;9:e90918.

26 Ort T, Voronov S, Guo J, Zawalich K, Froehner SC, Zawalich W, Solimena M: Dephosphorylation of beta2syntrophin and $\mathrm{Ca} 2+/ \mathrm{mu}$-calpain-mediated cleavage of ICA512 upon stimulation of insulin secretion. EMBO J 2001;20:4013-4023.

- 27 Hebel T, Eisinger K, Neumeier M, Rein-Fischboeck L, Pohl R, Meier EM, Boettcher A, Froehner SC, Adams ME, Liebisch G, Krautbauer S, Buechler C: Lipid abnormalities in alpha/beta2-syntrophin null mice are independent from ABCA1. Biochim Biophys Acta 2015;1851:527-536.

28 Lyssand JS, Lee KS, DeFino M, Adams ME, Hague C: Syntrophin isoforms play specific functional roles in the alpha1D-adrenergic receptor/DAPC signalosome. Biochem Biophys Res Commun 2011;412:596-601.

29 Granneman JG, Zhai Y, Lahners KN: Selective up-regulation of alpha1a-adrenergic receptor protein and mRNA in brown adipose tissue by neural and beta3-adrenergic stimulation. Mol Pharmacol 1997;51:644650.

- 30 Flechtner-Mors M, Jenkinson CP, Alt A, Adler G, Ditschuneit HH: In vivo alpha(1)-adrenergic lipolytic activity in subcutaneous adipose tissue of obese subjects. J Pharmacol Exp Ther 2002;301:229-233.

- 31 Wieser V, Adolph TE, Grander C, Grabherr F, Enrich B, Moser P, Moschen AR, Kaser S, Tilg H: Adipose type I interferon signalling protects against metabolic dysfunction. Gut 2018;67:157-165.

-32 Adams ME, Kramarcy N, Fukuda T, Engel AG, Sealock R, Froehner SC: Structural abnormalities at neuromuscular synapses lacking multiple syntrophin isoforms. J Neurosci 2004;24:10302-10309.

-33 Bauer S, Wanninger J, Schmidhofer S, Weigert J, Neumeier M, Dorn C, Hellerbrand C, Zimara N, Schaffler A, Aslanidis C, Buechler C: Sterol regulatory element-binding protein 2 (SREBP2) activation after excess triglyceride storage induces chemerin in hypertrophic adipocytes. Endocrinology 2011;152:26-35.

34 Krautbauer S, Eisinger K, Hader Y, Buechler C: Free fatty acids and IL-6 induce adipocyte galectin-3 which is increased in white and brown adipose tissues of obese mice. Cytokine 2014;69:263-271.

35 Krautbauer S, Eisinger K, Neumeier M, Hader Y, Buettner R, Schmid PM, Aslanidis C, Buechler C: Free fatty acids, lipopolysaccharide and IL-1alpha induce adipocyte manganese superoxide dismutase which is increased in visceral adipose tissues of obese rodents. PLoS One 2014;9:e86866.

36 Jo J, Gavrilova O, Pack S, Jou W, Mullen S, Sumner AE, Cushman SW, Periwal V: Hypertrophy and/or Hyperplasia: Dynamics of Adipose Tissue Growth. PLoS Comput Biol 2009;5:e1000324.

37 Buechler C, Bauer S: ATP binding cassette transporter A1 (ABCA1) associated proteins: potential drug targets in the metabolic syndrome and atherosclerotic disease? Curr Pharm Biotechnol 2012;13:319-330.

38 Lo KA, Sun L: Turning WAT into BAT: a review on regulators controlling the browning of white adipocytes. Biosci Rep 2013;33:e00065.

39 Khan T, Muise ES, Iyengar P, Wang ZV, Chandalia M, Abate N, Zhang BB, Bonaldo P, Chua S, Scherer PE: Metabolic dysregulation and adipose tissue fibrosis: role of collagen VI. Mol Cell Biol 2009;29:1575-1591.

40 Pellegrinelli V, Carobbio S, Vidal-Puig A: Adipose tissue plasticity: how fat depots respond differently to pathophysiological cues. Diabetologia 2016;59:1075-1088.

-41 Shirwany NA, Zou MH: AMPK: a cellular metabolic and redox sensor. A minireview. Front Biosci (Landmark Ed) 2014;19:447-474.

42 Takahashi-Yanaga F: Activator or inhibitor? GSK-3 as a new drug target. Biochem Pharmacol 2013;86:191199.

43 Sun K, Tordjman J, Clement K, Scherer PE: Fibrosis and adipose tissue dysfunction. Cell Metab 2013;18:470-477.

44 Huang IH, Hsiao CT, Wu JC, Shen RF, Liu CY, Wang YK, Chen YC, Huang CM, del Alamo JC, Chang ZF, Tang MJ, Khoo KH, Kuo JC: GEF-H1 controls focal adhesion signaling that regulates mesenchymal stem cell lineage commitment. J Cell Sci 2014;127:4186-4200.

45 Le Lay S, Hajduch E, Lindsay MR, Le Liepvre X, Thiele C, Ferre P, Parton RG, Kurzchalia T, Simons K, Dugail I: Cholesterol-induced caveolin targeting to lipid droplets in adipocytes: a role for caveolar endocytosis. Traffic 2006;7:549-561. 


\section{Cellular Physiology Cell Physiol Biochem 2019;52:1151-1165 \\ \begin{tabular}{ll|l} 
and Biochemistry & $\begin{array}{l}\text { DOl: 10.33594/000000078 } \\
\text { Published online: } 17 \text { April } 2019\end{array}$ & $\begin{array}{l}\text { O } 2019 \text { The Author(s). Published by } \\
\text { Cell Physiol Biochem Press GmbH\&Co. KG }\end{array}$ \\
\cline { 2 - 3 }
\end{tabular} \\ Krautbauer et al.: SNTB2 Deficiency Improves Metabolic Health in Obesity}

46 Sheng R, Chen Y, Yung Gee H, Stec E, Melowic HR, Blatner NR, Tun MP, Kim Y, Kallberg M, Fujiwara TK, Hye Hong J, Pyo Kim K, Lu H, Kusumi A, Goo Lee M, Cho W: Cholesterol modulates cell signaling and protein networking by specifically interacting with PDZ domain-containing scaffold proteins. Nat Commun 2012;3:1249.

47 Catalan V, Gomez-Ambrosi J, Rodriguez A, Silva C, Rotellar F, Gil MJ, Cienfuegos JA, Salvador J, Fruhbeck G: Expression of caveolin-1 in human adipose tissue is upregulated in obesity and obesity-associated type 2 diabetes mellitus and related to inflammation. Clin Endocrinol (Oxf) 2008;68:213-219.

-48 Fernandez-Real JM, Catalan V, Moreno-Navarrete JM, Gomez-Ambrosi J, Ortega FJ, Rodriguez-Hermosa JI, Ricart W, Fruhbeck G: Study of caveolin-1 gene expression in whole adipose tissue and its subfractions and during differentiation of human adipocytes. Nutr Metab (Lond) 2010;7:20.

49 Gomez-Ruiz A, Milagro FI, Campion J, Martinez JA, de Miguel C: Caveolin expression and activation in retroperitoneal and subcutaneous adipocytes: influence of a high-fat diet. J Cell Physiol 2010;225:206-213.

50 Gomez-Ruiz A, Milagro FI, Campion J, Martinez JA, de Miguel C: High-fat diet feeding alters metabolic response to fasting/non fasting conditions. Effect on caveolin expression and insulin signalling. Lipids Health Dis 2011;10:55.

51 Wu L, Zhou L, Chen C, Gong J, Xu L, Ye J, Li D, Li P: Cidea controls lipid droplet fusion and lipid storage in brown and white adipose tissue. Sci China Life Sci 2014;57:107-116.

52 Donnelly KL, Smith CI, Schwarzenberg SJ, Jessurun J, Boldt MD, Parks EJ: Sources of fatty acids stored in liver and secreted via lipoproteins in patients with nonalcoholic fatty liver disease. J Clin Invest 2005;115:1343-1351.

53 Duncan RE, Ahmadian M, Jaworski K, Sarkadi-Nagy E, Sul HS: Regulation of lipolysis in adipocytes. Annu Rev Nutr 2007;27:79-101.

- 54 Andersson DP, Eriksson Hogling D, Thorell A, Toft E, Qvisth V, Naslund E, Thorne A, Wiren M, Lofgren P, Hoffstedt J, Dahlman I, Mejhert N, Ryden M, Arner E, Arner P: Changes in subcutaneous fat cell volume and insulin sensitivity after weight loss. Diabetes Care 2014;37:1831-1836. 